\title{
Pengembangan Model Modifikasi Kurikulum Sekolah Inklusif Berbasis Kebutuhan Individu Peserta Didik
}

\author{
Abdul Salim \\ PLB UNS, e-mail: salimchoiri@fkip.uns.ac.id
}

\begin{abstract}
Abstrak: Penelitian ini bertujuan untuk mengembangkan model modifikasi kurikulum anak berkebutuhan khusus dan mengetahui validitas empiris modifikasi kurikulum. Pengumpulan data dilakukan melalui interview, observasi dan dokumentasi. Tehnik analisis data menggunakan deskriptif kualitatif. Hasil penelitian menunjukkan bahwa 1) Pemahaman guru dan kepala sekolah terhadap panduan modifikasi kurikulum menunjukkan :(a) sangat baik 46,93\%, (b) baik 32,65\%, (c) kurang baik 16,32\%, dan 4\% tidak baik. 2) Validitas empiris buku panduan menunjukkan bahwa: a). 88,2\% guru dan kepala sekolah menyetujui kebermaknaan/Substansi buku panduan dan $11 \%$ kurang menyetujui. b). $88,2 \%$ menyatakan buku panduan telah menggunakan bahasa yang baik dan sisanya $11,8 \%$ menyatakan belum. c) $88,2 \%$ menyatakan buku panduan telah menggunakan gaya penulisan yang singkat, padat dan baik, sedangkan sisanya $11,8 \%$ tidak menjawab pertanyaan. c). $64,7 \%$ menyatakan penampilan buku panduan telah memiliki penampilan yang baik, $29,4 \%$ belum baik dan $11,8 \%$ tidak menjawab pertanyaan.
\end{abstract}

Kata kunci: modifikasi kurikulum dan sekolah inklusif

\begin{abstract}
The aims of this research are to develop the model of modified curriculum for inclusive schools based on the individual needs and to know the empirical validity of the curriculum modified. The data is collected through interview, observation and documentation. The data is analysed by using descriptive technique. The result of this research show that: 1) The understanding of teachers and Headmaster Prinsipal in inclusive schools about the content of curriculum modified guidance book, such as: (a) $46 \%$ well understanding, (b) $32,65 \%$ good understanding, (c) $16,32 \%$ bad understanding (d) $4 \%$ worst understanding. 2).The empiric validities of guidance books of curriculum modification shows: (a) $88.2 \%$ teachers and head master have agreed the content of guidance books' substance the meaning/ the substance of guidance books, only $11.8 \%$ who are disagree. (b) The readability of guidance books: $88.2 \%$ guidance books have used proper language in its writing and only $11.8 \%$ which haven't used proper language yet. (c) $88.2 \%$ guidance books have used good and proper style of writing while out of $11,8 \%$ haven't answered the question. And (d) the appearance of guidance books: $64.7 \%$ respondents states that guidance books have had good appearance, 29.2\% consider that the appearance hasn't been good enough yet and the rest, $11.8 \%$ do not answer the question.
\end{abstract}

Key words: curriculum modification and inclusive schools.

\section{Pendahuluan}

Pada hakekatnya semua anak memiliki kesempatan yang sama untuk memperoleh pendidikan. Melalui pendidikan, seluruh potensi anak didik dapat digali dan dikembangkan secara optimal. Baik anak didik yang normal maupun berkelainan. Hal ini bertemali dengan amanat UUD 1945 pasal 31 ayat 1 dan ayat 2 tentang hak dan kewajiban setiap warga negara untuk mendapatkan pendidikan dan UU Nomor 20, Tahun 2003 pasal 5 ayat 1 tentang hak setiap warga negara memperoleh pendidikan yang bermutu. Dengan demikian tidak ada alasan untuk meniadakan pendidikan anak berkebutuhan khusus (ABK), apalagi menelantarkan $A B K$ dalam memperoleh pendidikan.

Peserta didik berkebutuhan khusus memiliki hambatan dalam mengikuti pembelajaran, hambatan itu mulai dari gradasi paling berat sampai dengan yang paling ringan. Bagi peserta didik yang memiliki hambatan berat, mereka dapat di didik di sekolah khusus atau Sekolah Luar Biasa (SLB) dan Sekolah Dasar Luar Biasa (SDLB). 
Sedangkan mereka yang memiliki hambatan belajar pada gradasi sedang dan ringan dapat dididik di sekolah umum/sekolah regular, dengan persyaratan tertentu. Pendidikan bagi ABK di sekolah umum/sekolah regular disebut sekolah inklusif. Tujuan pendidikan inklusif antara lain untuk mengatasi keterbatas-an jumlah SLB dan SDLB yang telah ada (karena SLB dan SDLB hnya mampu mendidik $1 \%$ dari $A B K$ usia sekolah) serta untuk mempercepat pencapaian program wajib belajar pendidikan dasar bagi ABK di Indonesia.

Permasalahan yang terkait dengan ABK antara lain: a) kurikulum yang tepat dan proporsional untuk digunakan sebagai acuan dalam pembelajaran; b) keterbatasan kemampuan guru dalam mengembangkan kurikulum khusus $A B K$; c) keterbatasan sarana dan prasarana dan; d) kesulitan guru dalam penilaian kemampuan $A B K$.

Secara umum, penelitian ini bertujuan untuk mengembangkan model modifikasi kurikulum untuk sekolah inklusif berbasis kebutuhan individual peserta didik. Secara khusus, penelitian bertujuan untuk: 1) mengembangkan model modifikasi kurikulum sekolah inklusif berbasis kebutuhan individu dan 2) mengetahui validitas empiris modifikasi kurikulum.

\section{Kajian Literatur}

\section{Pendidikan Inklusif}

Pendidikan inklusif pada dasarnya adalah pendidikan yang mengikutsertakan anak-anak yang memiliki kebutuhan khusus ( $A B K /$ penyandang cacat) untuk belajar bersama-sama dengan anak-anak lain sebayanya di sekolah umum. Menurut Konferensi Dunia tentang Pendidikan Luar Biasa pada bulan Juni 1994 di Salamanca bahwa prinsip mendasar dari pendidikan inklusif adalah selama memungkinkan, semua anak seyogyanya belajar bersama-sama tanpa memandang kesulitan ataupun perbedaan yang ada pada mereka.

Stainback dan Stainback (1990) mengemukakan bahwa sekolah inklusif adalah sekolah yang menampung semua siswa di kelas yang sama. Sekolah ini menyediakan program pendidikan yang layak, menantang, tetapi sesuai dengan kemampuan dan kebutuhan setiap anak, maupun bantuan dan dukungan yang dapat diberikan oleh para guru agar anak-anak berhasil. Lebih dari itu, sekolah inklusif juga merupakan tempat setiap anak dapat diterima, menjadi bagian dari kelas tersebut dan saling membantu dengan guru dan teman sebayanya, maupun anggota masyarakat lain agar kebutuhan individualnya dapat terpenuhi. Selanjutnya, Sunardi (2005) mengemukakan bahwa pendidikan inklusif menempatkan ABK tingkat ringan, sedang, dan berat secara penuh di kelas reguler. Hal ini menunjukkan bahwa kelas reguler merupakan tempat belajar yang relevan bagi $A B K$, dari semua jenis dan gradasi kelainan. Sementara itu, Skjorten (2000) mengemukakan bahwa pendidikan inklusif sebagai system layanan pendidikan yang mempersyaratkan: 1) ada ABK di sekolah umum; 2) ada dukungan dari komunitas sekolah; 3) kurikulum fleksibel; 4) pembelajaran bervariasi; 5) ada guru kelas dan guru khusus; 6) terjadi modifikasi tehnik evaluasi, dan 7) tidak ada anak tinggal kelas.

Pendidikan inklusif di Indonesia sudah dirintis sejak tahun 2003. Berdasarkan Surat Edaran Dirjen Dikdasmen Depdiknas No.380/C.66/MN/ 2003, 20 Januari 2003 perihal Pendidikan Inklusif bahwa di setiap Kabupaten/Kota di seluruh Indonesia sekurang-kurangnya harus ada 4 sekolah penyelenggara inklusif, yaitu di jenjang SD, SMP, SMA dan SMK masing-masing minimal satu sekolah. Sampai akhir tahun 2006 telah dirintis sebanyak 775 sekolah inklusif di Indonesia dengan perincian sebanyak 573 sekolah jenjang SD, 101 sekolah jenjang SMP dan 101 sekolah jenjang SMA. Penyelenggaraan pendidikan inklusif di Indonesia sekarang telah memiliki landasan yuridis yaitu Peraturan Menteri Pendidikan Nasional Nomor 70, Tahun 2009. Dalam implementasinya ternyata sekolah inklusif menemui banyak hambatan, baik hambatan yang berkaitan dengan kurikulum yang harus digunakan, keterbatasan kemampuan guru dalam mengembangkan kurikulum khusus, keterbatasan sarana dan prasarana, sampai pada kesulitan guru dalam penilaian kemampuan ABK.

Setiap anak hakekatnya berbeda satu dengan yang lainnya, baik kemampuan di bidang akademik maupun di bidang nonakademik. Kenyataan ini mengharuskan pendidik dalam mengembangkan kurikulum perlu mempertim- 
bangkan perbedaan-perbedaan peserta didik. Kurikulum yang digunakan di sekolah inklusif tentu tidak hanya kurikulum umum/reguler. Karena kurikulum regular hanya cocok untuk anak normal dan memiliki kemampuan homogen. Bagi ABK di sekolah inklusif seharusnya menggunakan kurikulum khusus yang telah disesuaikan dengan kebutuhan individual peserta didik ABK. Kurikulum khusus yang seharusnya ada di sekolah-sekolah inklusif dimaksud sampai sekarang belum ada.

Berdasarkan Peraturan Pemerintah Nomor 19, Tahun 2005 tentang Standar Nasional Pendidikan. Pemerintah memberikan arahan tentang perlunya disusun dan dilaksanakan delapan standar nasional pendidikan, yaitu standar isi, standar proses, standar kompetensi lulusan, standar pendidik dan tenaga kependidikan, standar sarana dan prasarana, standar pengelolaan, standar pembiayaan, dan standar penilaian pendidikan. Melalui kerja keras selama tahun 2006, Badan Standar Nasional Pendidikan (BSNP) sebagai badan mandiri dan independen yang bertugas mengembangkan, memantau pelaksanaan, dan mengevaluasi standar nasional pendidikan telah berhasil mengembangkan kurikulum khusus bagi $A B K$ dengan hambatan penglihatan, pendengaran, daksa/fisik, dan penyimpangan perilaku. Akan tetapi kurikulum khusus tersebut diperuntukan bagi sekolah khusus yaitu SLB dan SDLB, sedangkan untuk sekolah inklusif BSNP belum dapat mengembangkannya.

Dengan dikembangkannya "model modifikasi kurikulum untuk sekolah inklusif berbasis kebutuhan individual peserta didik" diharapkan dapat mengisi kekosongan kurikulum khusus di sekolah reguler serta mengatasi hambatan implementasi pendidikan inklusif di Indonesia.

Mutu pendidikan (Iulusan) dipengaruhi oleh mutu proses belajar-mengajar; sementara itu, mutu proses belajar-mengajar ditentukan oleh berbagai faktor (komponen) yang saling terkait satu sama lain, yaitu: a) Input siswa, b) Kurikulum (bahan ajar), c) Tenaga kependidikan (guru/ instruktur/pelatih), d) Sarana-prasarana, e) Dana, f) Manajemen (pengelolaan), dan g) Lingkungan (sekolah, masyarakat, dan keluarga), Secara diagramatis seperti Gambar 1.

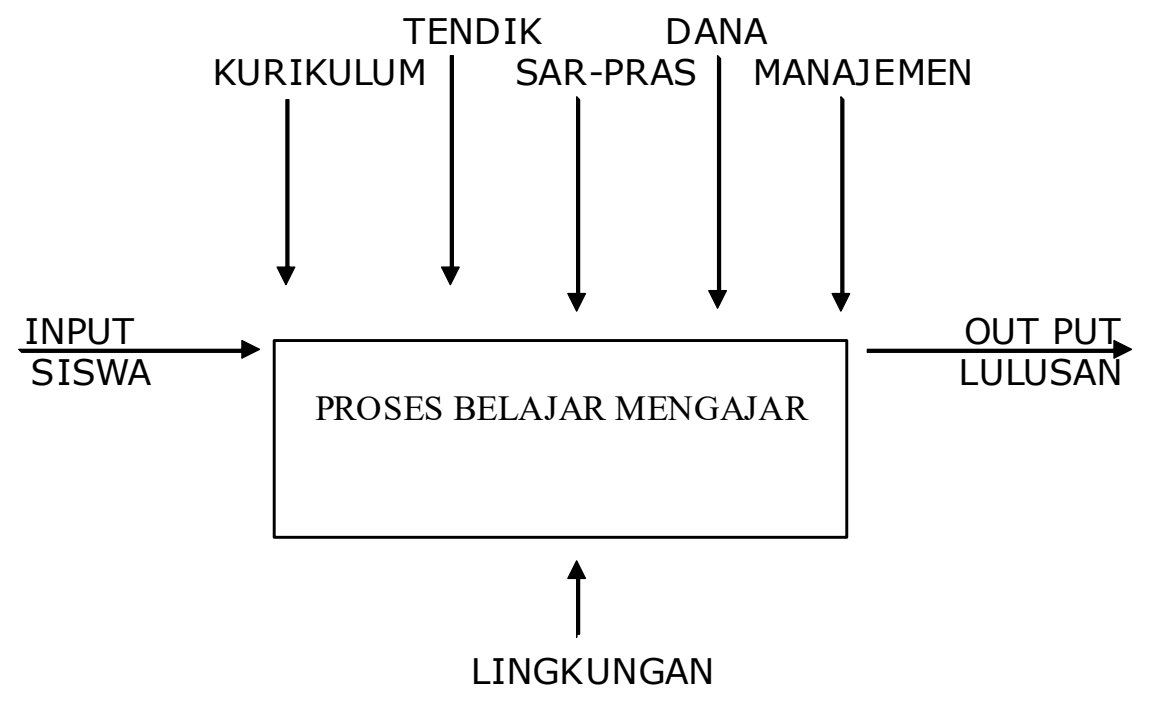

Gambar 1. Komponen yang berpengaruh pada mutu proses belajar mengajar 
Komponen-komponen tersebut merupakan subsistem dalam sistem pendidikan (sistem pembelajaran). Bila ada perubahan pada salah satu subsistem (komponen) maka menuntut perubahan/penyesuaian komponen lainnya. Dalam hal ini, bila dalam suatu kelas terdapat perubahan pada input siswa, yakni tidak hanya menampung anak normal tetapi juga ABK maka menuntut penyesuaian (modifikasi) kurikulum (bahan ajar), peran serta guru, sarana-prasarana, dana, manajemen (pengelolaan kelas), lingkungan, dan kegiatan belajar-mengajar.

Implikasinya, bahwa pendidikan inklusif akan sangat sulit diimplementasikan manakala komponen-komponen tersebut di atas tidak dilakukan modifikasi. Komponen pendidikan yang paling berat merasakan adalah komponen tenaga pendidik atau guru. Guru akan sangat sulit melaksanakan pembelajaran yang bermutu apabila kurikulum tidak dilakukan modifikasi, demikian juga komponen yang lain perlu diadakan penyesuaian. Mengapa guru yang paling terbebani?. Hal ini karena guru di sekolah umum tidak dididik dan dipersiapkan untuk melaksanakan pendidikan bagi anak normal.

Sementara itu, di sekolah inklusif dengan kehadiran ABK maka guru akan mengalami kesulitan. Kesulitan itu akan dapat dieliminasi manakala guru dibantu dengan dipersiapkan kurikulum khusus bagi $A B K$, baik $A B K$ tingkat ringan ataupun $A B K$ tingkat sedang.

Kecacatan pada dasarnya merupakan suatu kondisi atas hilangnya normalitas dari fungsi atau struktur anatomi, psikologi maupun fisiologi seseorang. Dengan kecacatan hidup seseorang menjadi terbatas serta memiliki kemampuan yang berbeda dari orang normal sehingga akan mempengaruhi keleluasaan aktivitas fisik, kepercayaan dan harga diri, hubungan dengan orang lain maupun dengan lingkungannya. Kondisi ini juga berakibat pada keterbatasan, kesempatan bergaul, bersekolah, bekerja dan bahkan menimbulkan perlakuan diskriminatif dari mereka yang tidak cacat. Hal inilah yang menyebabkan mereka berbeda dengan orang lain.

Pada dasarnya manusia berbeda-beda tidak hanya dalam umur, melainkan juga dalam warna kulit, karakteristik, kesenangan, kebiasaan, kemampuan, minat, dan lain-lain. Bagi dunia pendidikan kenyataan ini mengharuskan perlunya pendidik mempertimbangkan perbedaan-perbedaan peserta didik ketika merencanakan, melaksanakan, dan menilai pendidikan. Khusus untuk peserta didik berkebutuhan khusus ( $A B K$ ) terdapat perbedaan karakteristik dan kemampuan yang tampak menyolok pada hampir semua bidang akademik maupun nonakademik. Implikasi dari perbedaan yang bervariasi pada $A B K$ tersebut menyebabkan bentuk layanan pendidikan harus disesuaikan dengan kebutuhan masing-masing anak. Snell (dalam Sunardi, 2005) mengemukakan beberapa hal yang mendasari perlunya layanan pendidikan $A B K$ yang disesuaikan dengan kebutuhan individualnya, yaitu: a) ABK dalam belajar berbeda dengan anak normal, makin berat tingkat kecacatannya semakin komplek cara belajarnya. ABK memerlukan modifikasi dan rentang waktu yang berbeda dibandingkan dengan peserta didik yang normal; b) Sekolah bertanggung jawab memberikan keterampilan fungsional agar siswa dapat mandiri. Dengan demikian, diharapkan sekolah dapat mengajarkan keterampilan fungsional yang dibutuhkan siswa dalam menjalankan kehidupannya baik di sekolah, di rumah, dan di masyarakat; c) Guru harus berhubungan dengan orangtua peserta didik di dalam menjalankan program maupun evaluasi programnya; d) Guru sangat berperan dalam pencapaian tujuan pembelajaran. Guru juga harus dapat meyakinkan masyarakat bahwa tujuan materi dalam program pembelajaran individual dapat diterima: praktis, efektif, dan manusiawi; e) ABK membutuhkan pelayanan pendidikan dengan prinsip-prinsip modifikasi perilaku.

Pengakuan atas pentingnya perbedaan individual diperlukan baik dalam sistem pendidikan yang sifatnya individual maupun yang sifatnya klasikal. Bukan hanya siswa yang harus menyesuaikan diri kepada situasi dan subtansi pendidikan, melainkan juga sistem pendidikan yang harus menyesuaikan diri pada kemampuan, kesulitan, kecepatan, dan minat peserta didik. Artinya, ABK tidak dipaksa menguasai kompetensi yang di luar kemampuannya. Nanun tidak dikurung dalam bahan yang sudah ada karena ada sangkaan apriori bahwa bahan berikutnya terlalu sukar. ABK juga tidak diminta mengejar temannya yang lebih pintar, juga tidak didiamkan menunggu temannya yang lebih lambat. Siswa 
yang gagal dalam suatu metode dan teknik mengajar belum tentu akan gagal dalam metode dan teknik yang lain.

Dengan adanya perbedaan kemampuan individual maka Vaughn, Bos, dan Schumm (2000) menganjurkan penyediaan layanan pendidikan yang layak bagi $A B K$ sesuai dengan kebutuhan individualnya. Penempatan belajar ABK harus dipilih yang paling bebas di antara a) Kelas reguler (inklusif penuh), b) Kelas reguler dengan cluster, c) Kelas reguler dengan pull out, d). Kelas reguler dengan cluster dan pull out, e) Kelas khusus dengan berbagai pengintegrasian

Untuk mengurangi kesulitan-kesulitan yang sering dirasakan sekolah dalam implementasi pendidikan inklusif, beberapa pakar pendidikan luar biasa (Sunardi, 2005, Abdul Salim, 2005, 2008) menyarankan agar ABK yang mengikuti pendidikan inklusif di sekolah reguler hanyalah ABK dengan gradasi kesulitan tingkat ringan dan tingkat sedang. Sementara itu, ABK dengan gradasi kesulitan tingkat berat sebaiknya tetap memperoleh layanan pendidikan di sekolahsekolah khusus seperti SLB dan SDLB.

Sampai saat ini, di Indonesia belum ada pedoman penyelenggaraan pendidikan inklusif yang berkaitan dengan kurikulum. Dalam UndangUndang Nomor 20, Tahun 2003 tentang Sistem Pendidikan Nasional (UU 20/2003) pada pasal 1 butir 19 disebutkan bahwa Kurikulum adalah seperangkat rencana dan pengaturan mengenai tujuan, isi dan bahan pelajaran serta cara yang digunakan sebagai pedoman penyelenggaraan kegiatan pembelajaran untuk mencapai tujuan pendidikan tertentu. Tujuan tertentu ini meliputi tujuan pendidikan nasional serta kesesuaian dengan kekhasan, kondisi dan potensi daerah, satuan pendidikan dan peserta didik. Oleh sebab itu kurikulum disusun oleh satuan pendidikan untuk memungkinkan penyesuaian program pendidikan dengan kebutuhan dan potensi yang ada di daerah.

Pengembangan Kurikulum Tingkat Satuan Pendidikan (KTSP) yang beragam mengacu pada standar nasional pendidikan untuk menjamin pencapaian tujuan pendidikan nasional. UU 20/ 2003 dan Peraturan Pemerintah Republik Indonesia Nomor 19, Tahun 2005 (PP 19/2005) tentang Standar Nasional Pendidikan mengamanatkan kurikulum pada KTSP jenjang pendidikan dasar dan menengah disusun oleh satuan pendidikan dengan mengacu kepada Standar Isi (SI) dan Standar Kompetensi Lulusan (SKL) serta berpedoman pada panduan yang disusun oleh Badan Standar Nasional Pendidikan (BSNP). Selain itu, penyusunan KTSP juga harus mengikuti ketentuan lain yang menyangkut kurikulum dalam UU 20/2003 dan PP 19/2005.

Dalam konteks sekolah inklusif maka KTSP tidak hanya satu macam, karena keberadaan ABK di sekolah tersebut. Artinya, di samping ada KTSP yang dikembangkan dengan mengacu pada Standar Kompetensi (SK) dan Kompetensi Dasar (KD) yang terdapat dalam SI dan SKL, juga mengembangkan program pembelajaran individual (PPI) atau IEP (Individualized Educational Program) yang dikembangkan mengacu pada kurikulum khusus yang memuat standar kompetensi dan kompetensi dasar untuk satuan pendidikan dasar yang masih harus dikembangkan.

Secara skematik kebutuhan pengembangan kurikulum khusus di sekolah inklusif dipolakan pada Gambar 2.

Gambar 2 menunjukkan bahwa di sekolah inklusif terdapat: 1) kurikulum reguler atau KTSP yang dikembangkan berpedoman pada SK dan KD yang dikembangkan BSNP, dan 2) IEP atau PPI yang dikembangkan berdasarkan "Kurikulum Khusus" atau "Kurikulum Modifikasi".

Mengingat kurikulum khusus atau untuk sekolah inklusif belum ada maka kurikulum modifikasi tersebut mendesak dikembangkan. SK dan KD yang ada dalam kurikulum modifikasi akan menjadi arah dan landasan untuk mengembangkan materi pokok, kegiatan pembelajaran, dan indikator pencapaian kompetensi untuk penilaian, dengan mempertimbangkan kemampuan individual peserta didik. Hasilnya dituangkan dalam IEP atau PPI yang dikembangkan oleh Guru Pendidikan Khusus (GPK). Kerangka pikir penelitian ini disajikan pada Gambar 3. 


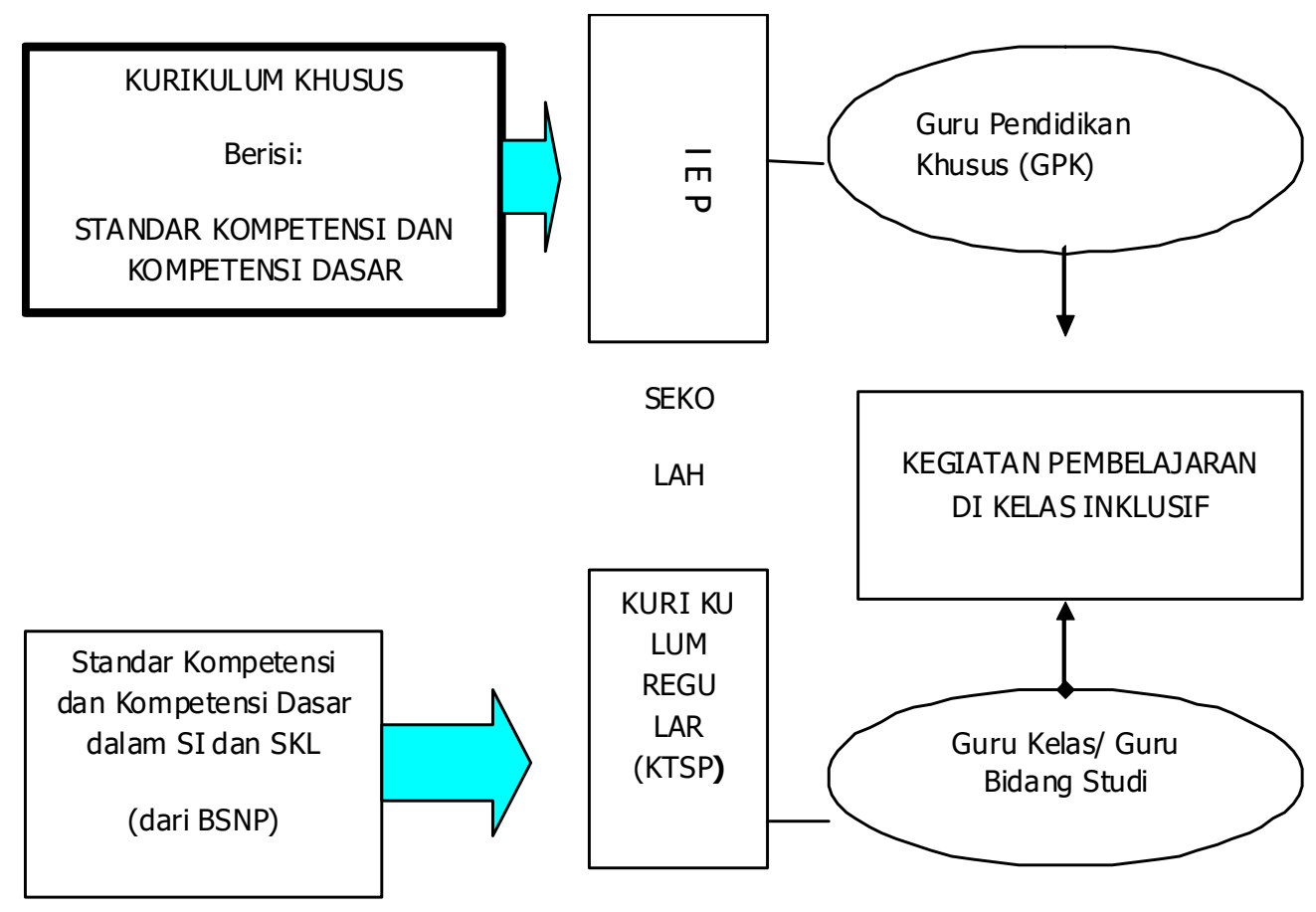

Gambar 2. Kebutuhan Pengembangan Kurikulum Khusus di Sekolah Inklusif

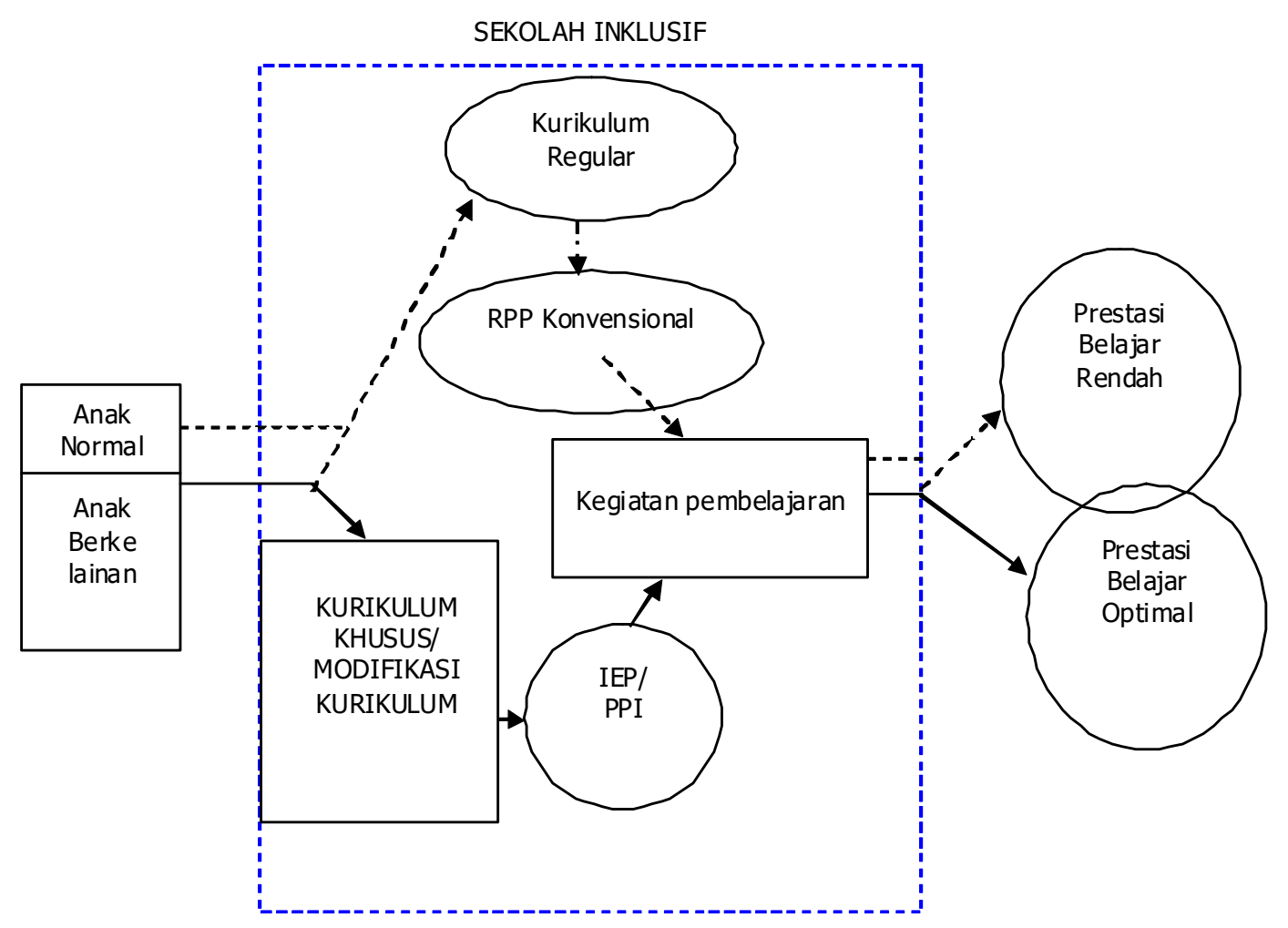

Gambar 3. Kerangka Pikir Penelitian 
Gambar 3 menunjukkan bahwa ABK di sekolah inklusif apabila dikenakan pembelajaran yang dirancang (RPP) bertolak dari kurikulum reguler, maka prestasi belajarnya akan rendah. Hal ini karena pembelajaran yang diberikan tidak/belum mempertimbangkan karakteristik dan kebutuhan individual peserta didik ABK. Sebaliknya, apabila ABK di sekolah inklusif diberikan pembelajaran yang perencanaannya (IEP) disusun berdasarkan kurikulum modifikasi dimungkinkan prestasi belajarnya menjadi optimal.

\section{Metode Penelitian}

Penelitian ini menggunakan pendekatan penelitian pengembangan ( $R \& D$ ), yang memuat 3 komponen (Sunarto, 2005), yaitu: 1) model pengembangan; 2) prosedur pengembangan; dan 3) ujicoba model yang dikembangkan.

\section{Model pengembangan}

Model pengembangan yang dipilih adalah model prosedural dari Borg dan Gall (1983, dalam Sunarto, 2005), yang bersifat deskriptif menunjukkan ada 5 langkah dalam model pengembangan disajikan pada gambar 4 .

\section{Prosedur pengembangan}

Prosedur atau langkah-langkah kegiatan penelitian sebagai berikut: a) Analisis model yang akan dikembangkan. Kegiatan yang dilakukan meliputi (1) Melakukan penelitian pendahuluan untuk mengumpulkan informasi (kajian pustaka, pengamatan sekolah inklusif, menggali dokumen asesmen) tentang kebutuhan dan komponen model yang diperlukan, (2) Melakukan perencanaan, seperti identifikasi komponen model yang perlu dikembangkan, langkah-langkah pengembangan, perencanaan uji validasi ahli, perencanaan ujicoba skala kecil, uji coba skala besar, b) Pengembangan model awal, kegiatannya meliputi: (1) Pengembangan model modifikasi kurikulum level I (untuk ABK hambatan ringan), (2) Pengembangan model modifikasi kurikulum level II (untuk ABK hambatan sedang), c) Validasi ahli dan revisi model (pertama), kegiatannya meliputi (1) Mengadakan FGD (Focus Group Discussion) untuk mereviu model awal yang sudah dikem-bangkan, (2) melakukan revisi/perbaikan 1, Perbaikan/revisi 1, d) Uji coba lapangan skala kecil dan revisi model (kedua), kegiatannya meliputi:

(1) Sosialisasi Model modifikasi kurikulum berbasis potensi individual peserta didik ABK level 1 dan 2, (2) Pelatihan penyusunan IEP atau PPI, (3) Pelatihan kegiatan pembelajaran berdiferensiasi, (4) Pelatihan penilaian di kelas inklusif, (5) Implementasi model modifikasi kurikulum level I dan II di sekolah inklusif, (6) Evaluasi validitas empirik model modifikasi kurikulum level I dan II di sekolah inklusif yang dikembangkan, (7) Perbaikan/revisi 2, e) Ujicoba lapangan skala besar dan finalisasi model akhir. Dalam hal ini macam dan langkah kegiatan sama dengan yang ada pada tahap uji coba lapangan skala terbatas, hanya saja jumlah sekolah uji coba dan cakupan

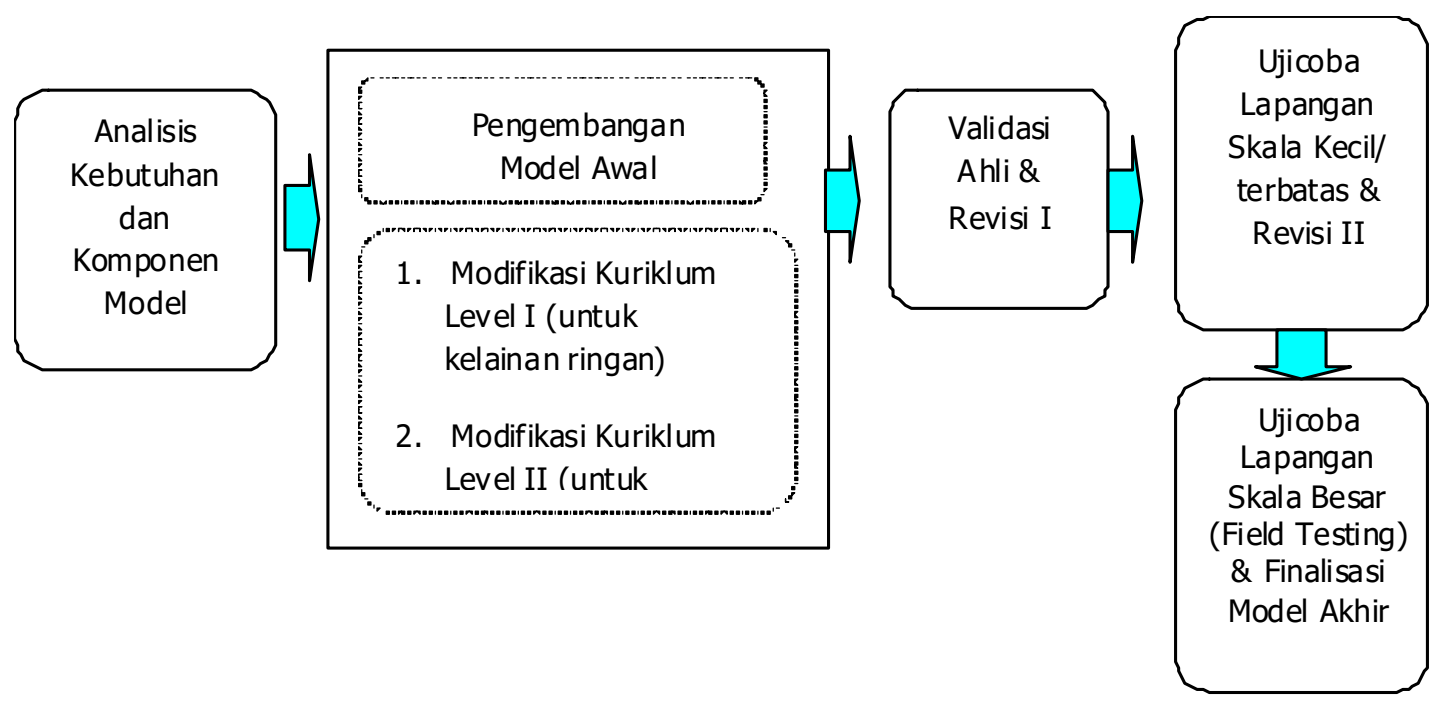

Gambar 4. Model Pengembangan Kurikulum Sekolah Inklusif 
wilayah lebih besar. Kemudian dilanjutkan dengan telaah uji lapangan, revisi 3, dan desiminasi.

\section{Uji coba model yang dikembangkan}

Uji coba dilakukan 3 kali, yaitu: (a) uji-ahli; (b) ujicoba lapangan (empirik) terbatas dilakukan terhadap kelompok kecil (satu sekolah inklusif); dan (c) ujicoba lapangan (empirik) skala besar (field testing).

\section{Desain Ujicoba}

Tiga tahapan ujicoba model modifikasi kurikulum level 1 dan 2 yang dikembangkan dapat dilihat pada Gambar 5.

\section{Jenis data}

Jenis dan macam data yang dikumpulkan dalam penelitian meliputi: 1) Kecermatan isi kurikulum khusus/ modifikasi kurikulum yang dikembangkan; 2) Keterbacaan kurikulum khusus/modifikasi kurikulum dan kejelasan petunjuk pelaksanaan; dan 3) Ketepatan sistimatika

\section{Tehnik Pengumpulan data dan instrumen}

Sesuai dengan macam data yang dikumpulkan dalam penelitian, maka metode yang digunakan untuk mengumpulkan data meliputi: metode interview, observasi dan kuesioner. Dilihat dari macam data, metode pengumpulan data, sumber

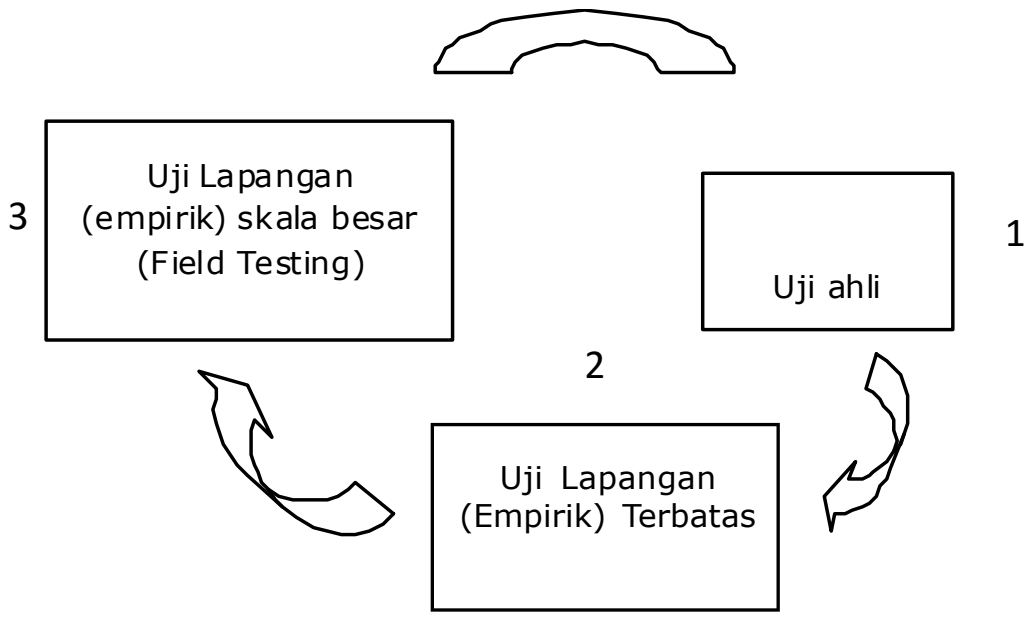

Gambar 5. Tiga Tahap Ujicoba

\section{Subyek Ujicoba}

Subyek ujicoba dilihat dari tahapan ujicoba dan karakteristik subyek adalah sebagai berikut.

\begin{tabular}{|ll|l|l|l|}
\hline $\begin{array}{l}\text { Tahapan uji } \\
\text { coba } \\
\text { Awal, uji ahli }\end{array}$ & $\begin{array}{l}\text { Jumlah } \\
\text { sampel } \\
30-50\end{array}$ & $\begin{array}{l}\text { Karakteristik sampel } \\
\text { Ahli kurikulum, anggota Tim BSNP, } \\
\text { Ahli Pendidikan Khusus, Kepala } \\
\text { Sekolah Inklusif, Kepala SLB, } \\
\text { Kepala SDLB, Pejabat dinas } \\
\text { Pendidikan Kota/Kabupaten, }\end{array}$ & $\begin{array}{l}\text { Tehnik } \\
\text { sampling } \\
\text { purposive }\end{array}$ & $\begin{array}{l}\text { Proses, Orientasi, dan } \\
\text { hasil uji coba } \\
\text { Kualitatif (FGD), } \\
\text { kuesioner, interview, } \\
\text { draf awal model } \\
\text { modifikasi kurikulum } \\
\text { level 1 dan 2, } \\
\text { kesesuaian substansi. }\end{array}$ \\
\hline $\begin{array}{l}\text { Utama } \\
\text { kelompok kecil }\end{array}$ & $20-30$ & $\begin{array}{l}\text { Pengguna model yang } \\
\text { dikembangkan pada sekolah } \\
\text { inklusif }\end{array}$ & random \\
$\begin{array}{l}\text { Uji lapangan } \\
\text { operasional, } \\
\text { tahap akhir }\end{array}$ & $30-50$ & $\begin{array}{l}\text { Pengguna model yang sebenarnya } \\
\text { beberapa sekolah inklusif di Kota } \\
\text { Surakarta }\end{array}$ & $\begin{array}{l}\text { kespenen, } \\
\text { kesuaian model } \\
\text { dengan pelaksana } \\
\text { Model yang Siap pakai, }\end{array}$ \\
\hline
\end{tabular}


data dan instrumen yang digunakan adalah sebagai berikut.

\begin{tabular}{|ll|l|l|l|}
\hline Macam data & $\begin{array}{l}\text { Metode } \\
\text { pengump. } \\
\text { data }\end{array}$ & Sumber data & $\begin{array}{l}\text { Instrumen/media yang } \\
\text { digunakan }\end{array}$ \\
\hline $\begin{array}{l}\text { 1. } \\
\text { Kecermatan isi model modifikasi } \\
\text { kurikulum level I dan II yang } \\
\text { dikembangkan }\end{array}$ & interview & Responden ahli & $\begin{array}{l}\text { Form isian pengemb } \\
\text { sendiri, FGD }\end{array}$ \\
\hline $\begin{array}{l}\text { Keterbacaan model modifikasi } \\
\text { kurikulum level I dan II dan } \\
\text { petunjuk pelaks } \\
\text { Ketepatan sistimatika model } \\
\text { modifikasi kurikulum level I dan II }\end{array}$ & interview & Responden ahli & $\begin{array}{l}\text { Form isian pengemb } \\
\text { sendiri, FGD }\end{array}$ \\
\hline
\end{tabular}

\section{Tehnik analisis data}

Data penelitian bersifat kualitatif. Mengingat sifat data tersebut, maka tehnik analisis data yang digunakan pada penelitian adalah sebagai berikut.

Analisis deskriptif untuk mendeskripsikan seluruh data dan hasil-hasil penelitian berkaitan dengan model modifikasi kurikulum yang dikembangkan, termasuk kecermatan isi, keterbacaan dan keberjalanan model dalam ujicoba.

\section{Hasil Dan Pembahasan}

Sesuai dengan tujuan khusus penelitian, maka penelitian ini telah berhasil dikembangkan hal-hal berikut.

\section{Model Modifikasi Kurikulum Anak Berkebutuhan Khusus}

Yang dimodifikasi di sini adalah isi kurikulum yang meliputi penyesuaian Standar Kompetensi dan
Kompetensi Dasar (SK KD) Mata Pelajaran PKN, Bahasa Indonesia, Matematika, IPA, dan IPS untuk $\mathrm{SD} / \mathrm{MI}$. Modifikasi isi kurikulum ini dinamakan prototipe model/panduan. Dalam penelitian ini prototipe model terdiri dari a) Prototipe model panduan modifikasi kurikulum level I (untuk anak kelainan ringan), b) Prototipe model panduan modifikasi kurikulum level II (untuk anak kelainan sedang)

Prototipe ini dikembangkan dengan mengkaji SK KD berdasarkan substansi keilmuan dan kemudian dilakukan pengurangan pada bagianbagian tertentu untuk disesuaikan dengan kemampuan dan hambatan yang dialami peserta didik tingkat ringan dan sedang.

Hasil pengkajian SK KD pada lima pelajaran di tingkat SD/MI disajikan pada Tabel 1.

Tabel 1. Ringkasan Hasil Modifikasi SK-KD Untuk Anak Dengan Hambatan Belajar Ringan

\begin{tabular}{|c|c|c|c|}
\hline Mata Pelajaran & SK-KD Lama & SK-KD Modifikasi & Prosentase \\
\hline 1. Bahasa Indonesia & $\begin{array}{l}\text { SK } 48 \text { buah } \\
\text { KD } 122 \text { buah }\end{array}$ & $\begin{array}{l}\text { SK } 48 \text { buah } \\
\text { KD } 97 \text { buah }\end{array}$ & $79.56 \%$ \\
\hline 2. I P A & $\begin{array}{l}\text { SK : } 42 \text { buah } \\
\text { KD: } 120 \text { buah }\end{array}$ & $\begin{array}{l}\text { SK : } 42 \text { buah } \\
\text { KD: } 95 \text { buah }\end{array}$ & $79.1 \%$ \\
\hline 3. I P S & $\begin{array}{l}\text { SK } 13 \text { buah } \\
\text { KD } 48 \text { buah }\end{array}$ & $\begin{array}{l}\text { SK } 13 \text { buah } \\
\text { KD } 38 \text { buah }\end{array}$ & $79,16 \%$ \\
\hline 4. PKN & $\begin{array}{l}\text { SK } 24 \text { buah } \\
\text { KD } 58 \text { buah }\end{array}$ & $\begin{array}{l}\text { SK } 24 \text { buah } \\
\text { KD } 47 \text { buah }\end{array}$ & $81,034 \%$ \\
\hline 5. Matematika & $\begin{array}{l}\text { SK } 36 \text { buah } \\
\text { KD } 123 \text { buah }\end{array}$ & $\begin{array}{l}\text { SK } 36 \text { buah } \\
\text { KD } 98 \text { buah }\end{array}$ & $79,67 \%$ \\
\hline
\end{tabular}


Tabel 2. Ringkasan Hasil Modifikasi SK-KD Untuk Anak Dengan Hambatan Belajar Sedang

\begin{tabular}{|l|l|l|l|}
\hline Mata Pelajaran & SK-KD Lama & SK-KD Modifikasi & Prosentase \\
\hline 1. Bahasa Indonesia & $\begin{array}{l}\text { SK 48 buah } \\
\text { KD 122 buah }\end{array}$ & $\begin{array}{l}\text { SK 48 buah } \\
\text { KD 72 buah }\end{array}$ & $59.01 \%$ \\
\hline 2. I P A & $\begin{array}{l}\text { SK }: 42 \text { Buah } \\
\text { KD: 120 Buah }\end{array}$ & $\begin{array}{l}\text { SK : 42 Buah } \\
\text { KD: 77 Buah }\end{array}$ & $64,1 \%$ \\
\hline 3. I P S & $\begin{array}{l}\text { SK 13 buah } \\
\text { KD 48 buah }\end{array}$ & $\begin{array}{l}\text { SK 13 buah } \\
\text { KD 28 buah }\end{array}$ & $58.3 \%$ \\
\hline 4. PKN & $\begin{array}{l}\text { SK 24 buah } \\
\text { KD 58 buah }\end{array}$ & $\begin{array}{l}\text { SK 24 buah } \\
\text { KD 36 buah }\end{array}$ & $62.067 \%$ \\
\hline 5. Matematika & $\begin{array}{l}\text { SK 36 Buah } \\
\text { KD 123 Buah }\end{array}$ & $\begin{array}{l}\text { SK 36 Buah } \\
\text { KD 80 Buah }\end{array}$ & $65 \%$ \\
\hline
\end{tabular}

Dari Tabel 1 dan 2 di atas diketahui bahwa untuk anak berkebutuhan khusus dengan hambatan belajar ringan, KD yang ada di kurikulum regular dikurangi sekitar $20 \%$. Sedangkan untuk anak berkebutuhan khusus dengan hambatan belajar sedang, maka KD dalam kurikulum regular dikurangi sekitar $40 \%$.

Pengurangan KD didasarkan pertimbanganpertimbangan berikut: a) Kompetensi dasar yang dirancang terlalu sulit dicapai oleh anak berkebutuhan khusus; b) Kompetensi dasar tertentu mungkin dapat dikuasai anak berkebutuhan khusus tetapi perlu dimasukkan pada semester/kelas yang lebih tinggi; dan c) Ada kompetensi dasar tertentu yang substansinya sudah tercakup pada kompetensi dasar yang lainnya (ada duplikasi).

\section{Validitas empiris model modifikasi kurikulum}

\section{Implementasi model kurikulum modifikasi}

Para guru sekolah dasar inklusif yang menjadi tempat ujicoba diminta menerapkan kurikulum modifikasi dalam pembelajaran anak berkebutuhan khusus.

Indikator yang digunakan adalah: 1) Guru kelas telah: (a) menyusun rencana pembelajaran individual berbasis kurikulum modifikasi, (b) melaksanakan kegiatan pembelajaran dengan PPI yang dikembangkan, dan (c) mencatat perkembangan/kemajuan anak; 2) Kepala sekolah telah: (a) Mengesahkan rencana pembelajaran individual yang disusun guru, (b) Menyaksikan guru kelas melaksanakan pembelajaran berbasis PPI, dan (c) Kepala Sekolah telah menyaksikan kemajuan anak dalam kegiatan sehari-hari; 3) Menurut pengakuan peserta didik bahwa: (a) guru pernah memberi pembelajaran dan (b) anak pernah melaksanakan kegiatan pembelajaran.
Adapun tolok ukur yang digunakan untuk menentukan keberjalanan model modifikasi kurikulum adalah apabila $60 \%$ guru kelas dan kepala SD menyetujui atau memberikan jawaban sesuai dengan indikator-indikator.

Tabel 3. Data jumlah rata-rata skor keberjalanan model modifikasi kurikulum

\begin{tabular}{|rl|r|r|r|r|l|}
\hline No & $\begin{array}{c}\text { Sumber } \\
\text { Data }\end{array}$ & Jumlah & $\begin{array}{c}\text { Jumlah } \\
\text { Skor }\end{array}$ & $\begin{array}{c}\text { Skor } \\
\text { maks }\end{array}$ & $\begin{array}{c}\text { Rata2 } \\
\text { skor }\end{array}$ & $\%$ \\
\hline 1. & Guru kelas & 15 & 180 & 14 & 12 & \\
\hline 2. & Kepala SD & 5 & 20 & 5 & 4 & \\
\hline 3. & Peserta didik & 21 & 117 & 7 & 5.57 & \\
\hline & Jumlah & & & 26 & 21.57 & \\
\hline \multicolumn{6}{|c|}{$21.57: 26 \times 100=82.96$} \\
\hline
\end{tabular}

Dari tabel 3 diketahui bahwa jumlah rata-rata skor hasil wawancara guru kelas, kepala SD dan peserta didik berkebutuhan khusus sebanyak 21.57 , dengan prosentase keberjalanan layanan rehabilitasi sebesar $82.96 \%$.

Dengan demikian, dilihat dari tolok ukur keberjalanan model modifikasi kurikulum yang digunakan dalam penelitian ini, maka dapat dikatakan bahwa keberjalanan model modifikasi kurikulum untuk sekolah inklusif $82.96 \%$.

\section{Pemahaman guru dan kepala tentang isi buku panduan}

Pemahaman guru dan kepala sekolah tentang buku panduan modifikasi kurikulum di sini dibedakan menjadi empat, yaitu "sangat baik", "baik", "kurang baik" dan "tidak baik". Data ini diperoleh berdasarkan skala penilaian yang diisi oleh para guru dan kepala sekolah.

Berdasarkan hasil pengumpulan data dan analisis deskriptif diketahui bahwa: 
Pemahamannya sangat baik, 46,93\%, Pemahamannya yang baik $32,65 \%$, Pemahamannya kurang baik $16,32 \%$, Pemahamannya tidak baik $4 \%$.

Selanjutnya apabila dilihat dari aspek validitas empiris buku panduan, maka digunakan pedoman penilaiannya sbb:

Jumlah prosentase:

(a) $<50 \% \quad$ : kurang valid

(b) $51 \%-75 \%$ : cukup valid

(c) $76 \%-100 \%$ : Sangat valid

Bertolak dari pedoman di atas, maka hasil analisis validitas empiris buku panduan diperoleh hasil sebagai berikut: a) Kebermaknaan/Substansi buku panduan: Sebagian besar $(88,2 \%)$ guru dan kepala sekolah telah setuju isi substansi buku panduan. Dan hanya $11,8 \%$ yang kurang setuju. b) Keterbacaan buku panduan: 1) Sebanyak $88,2 \%$ buku panduan telah menggunakan bahasa yang baik dalam penulisan, hanya $11,8 \%$ yang belum, 2) Sebanyak $88,2 \%$ buku panduan telah menggunakan gaya penulisan yang singkat, padat dan baik. Sebanyak 11,8\% tidak menjawab pertanyaan, c) Penampilan buku panduan.

Penampilan buku panduan meliputi aspek ukuran buku, tata letak, tipe huruf, konsistensi penomoran, pewarnaan dan kesan umum tampilan buku panduan. Hasil analisis data menunjukkan bahwa sebanyak $64,7 \%$ buku panduan telah memiliki penampilan yang baik, selebihnya $29,4 \%$ belum baik dan $11,8 \%$ tidak menjawab pertanyaan.

Pendidikan inklusif sebagai wacana baru dalam bidang pendidikan memerlukan pedoman dalam sistem penyelenggaraannya. Karena sekolah inklusif tidak semua peserta didiknya memiliki kemampuan yang normal. Panduan dalam modifikasi kurikulum untuk penyelenggaraan sekolah inklusi merupakan salah satu komponen yang diperlukan oleh para guru, agar guru dapat melakukan penyesuaian kurikulum reguler untuk dimodifikasi sesuai dengan kebutuhan peserta didik berkebutuhan khusus yang mengalami hambatan belajar.

Mengembangkan model atau pedoman modifikasi kurikulum dengan melakukan penyesuaian isi kurikulum regular (SK-KD) merupakan cara yang sesuai dengan peraturan perundang- undangan yang berlaku. Adapun perundangundangan yang menjadi landasan dalam pengembangan dan implementasi kurikulum dalam program inklusi, adalah UU No. 20/2003 tentang Sistem Pendidikan Nasional khususnya pasal 5 ayat 1, 2, pasal 5, 612 dan pasal 36 . Demikian juga didasarkan pada Peraturan Pemerintah No. 19/2005 tentang Standar Nasional Pendidikan, khususnya pasal 1 ayat 13 , yang menyatakan bahwa Kurikulum adalah seperangkat rencana dan pengaturan mengenai tujuan, isi, dan bahan pelajaran serta cara yang digunakan sebagai pedoman penyelenggaraan kegiatan pembelajaran untuk mencapai tujuan pendidikan tertentu.

Penelitian ini telah mengem bangkan modul modifikasi kurikulum melalui penyesuaian isi kurikulum regular sesuai kemampuan anak berkebutuhan khusus tingkat ringan dan sedang. Penyesuaian itu berupa pengurangan KD sekitar $20 \%$ untuk anak berkelainan ringan dan sekitar $40 \%$ untuk anak berkelainan sedang.

Sebagaimana diketahui bahwa hasil modifikasi isi kurikulum terhadap ke lima bidang studi utama di SD/MI, yaitu bidang studi bahasa Indonesia, IPA, IPS, PKN dan matematika sebagai berikut: a) Hambatan belajar tingkat ringan: Bahasa Indonesia $79.56 \%$, IPA $79.1 \%$, IPS $79,16 \%$, PKN 81,034\% dan matematika 79,67\%. Ini berarti modifikasinya mengalami pengu rangan kompetensi dasar sebesar sekitar $20 \%$. b) Hambatan belajar tingkat sedang: Bahasa Indonesia 59.01\%, IPA 64,1\%, IPS 53,3\%, PKN $62,06 \%$ dan matematika $62,06 \%$. Ini berarti modifikasinya mengalami pengurangan kompetensi dasar sebesar sekitar $40 \%$.

Hasil penelitian ini sesuai dengan pendapat Suharso pakar rehabilitasi anak cacat Indonesia (Abdul Salim, 2005; 2009) bahwa anak berkelainan ringan memiliki hambatan dalam belajar walaupun pada gradasi minimal, yaitu sekitar $20 \%$. Bantuan orang lain diperlukan, tetapi masih sangat minim. Sebaliknya bagi anak berkelainan tingkat sedang, mereka sudah membutuhkan bantuan orang lain yang lebih banyak, karena hambatannya sekitar $40 \%$.

Keberadaan anak-anak berkebutuhan khusus di kelas inklusif juga menuntut guru melakukan modifikasi metode yang digunakan dalam pembelajaran. 
Metode pembelajaran sebagai cara-cara yang berbeda untuk mencapai hasil pembelajaran yang berbeda di bawah kondisi yang berbeda. Metode pembelajaran ini diacukan sebagai caracara yang dapat digunakan dalam kondisi tertentu untuk mencapai hasil pembelajaran yang diinginkan. Cara-cara ini disebut juga sebagai strategi pembelajaran. Variabel metode pembelajaran diklasifikasi menjadi 3 jenis, yaitu: 1) strategi pengorganisasian; 2) strategi penyampaian; dan 3) strategi pengelolaan.

\section{Strategi Pengorganisasian Pembelajaran}

Yang dimaksudkan di sini adalah metode untuk mengorganisasi isi bidang studi yang telah dipilih untuk pembelajaran. Mengorganisasi mengacu pada suatu tindakan seperti pemilihan isi, penataan isi, pembuatan diagram, format, dan lainnya yang setingkat dengan itu.

Ada tiga strategi pembelajaran bagi anak luar biasa/anak berkelainan di kelas inklusi, yaitu: 1) Pembelajaran kompetitif; 2) Pembelajaran individual; 3) Pembelajaran kooperatif (Abdul Salim, Munawir Yusuf, 2009).

Pemilihan salah satu dari model pembelajaran di atas sangat tergantung pada: a) kondisi kemampuan anak berkelainan; b) kemampuan guru; c) jumlah guru; serta d) sarana dan prasarana yang tersedia.

Strategi pengorganisasian pembelajaran lebih lanjut dapat dibedakan menjadi 2 jenis, yaitu: strategi makro dan strategi mikro. Strategi makro: mengacu kepada metode untuk mengorganisasi isi pembelajaran yang melibatkan lebih dari satu konsep, atau prosedur, atau prinsip. Strategi mikro: mengacu kepada metode untuk mengorganisasi isi pembelajaran yang berkisar pada satu konsep, atau prosedur, atau prinsip. Strategi makro berurusan dengan bagaimana memilih, menata urutan, membuat sintesis, dan rangkuman isi pembelajaran (apakah konsep, prinsip, atau prosedur) yang saling berkaitan. Pemilihan isi, berdasarkan tujuan pembelajaran yang ingin dicapai, mengacu kepada penetapan konsepkonsep, atau prinsip-prinsip, atau prosedurprosedur yang diperlukan untuk mencapai tujuan itu. Penataan urutan isi mengacu kepada keputusan untuk menata dengan urutan tertentu konsep-konsep, atau prinsip-prinsip yang akan diajarkan. Pembuatan sistesis mengacu kepada keputusan tentang bagaimana cara menunjukkan keterkaitan di antara konsep-konsep, atau prinsip-prinsip. Pembuatan rangkuman mengacu kepada keputusan tentang bagaimana cara melakukan tinjauan ulang konsep-konsep, atau prinsip-prinsip serta kaitan-kaitan yang sudah diajarkan.

Strategi Penyampaian. Strategi penyampaian isi pembelajaran merupakan komponen variabel metode untuk melaksanakan program pembelajaran. Sekurang-kurangnya ada 2 fungsi dari strategi ini (Budiyanto, 2005) yaitu: 1) menyampaikan isi pembelajaran kepada pebelajar; dan 2) menyediakan informasi/bahanbahan yang diperlukan pebelajar untuk menampilkan unjuk kerja (seperti latihan dan tes). Strategi penyampaian mencakup lingkungan fisik, Guru, bahan-bahan pembelajaran, dan kegiatankegiatan yang berkaitan dengan pembelajaran. Atau, dengan kata lain, media merupakan satu komponen penting dari strategi penyampaian pembelajaran. Itulah sebabnya, media pembelajaran merupakan bidang kajian utama strategi ini.

Secara lengkap ada 3 komponen yang perlu diperhatikan dalam mempreskripsikan strategi penyampaian: 1 ) media pembelajaran; 2 ) interaksi pembelajar dengan media; dan 3) bentuk/struktur belajar mengajar. Media pembelajaran adalah komponen strategi penyampaian yang dapat dimuati pesan yang akan disampaikan kepada pembelajar, apakah itu orang, alat, atau bahan. Ada 5 cara dalam mengklasifikasi media pembelajaran untuk keperluan mempreskripsikan strategi penyampaian, yaitu: 1) tingkat kecermatan representasi; 2) tingkat interaktif yang mampu ditimbulkannya; 3) tingkat kemampuan khusus yang dimilikinya; 4) tingkat motivasi yang mampu ditimbulkannya; dan 5) tingkat biaya yang diperlukan. Interaksi pebelajar dengan media adalah komponen strategi penyampaian pembelajaran yang mengacu kepada kegiatan apa yang dilakukan oleh pebelajar dan bagaimana peranan media dalam merangsang kegiatan belajar itu. Bentuk belajar mengajar adalah komponen strategi penyampaian pembelajaran yang mengacu kepada apakah Siswa (pebelajar) belajar dalam kelompok besar, kelompok kecil, perseorangan, ataukah mandiri. 
Strategi Pengelolaan. Strategi pengelolaan pembelajaran merupakan komponen variabel metode yang berurusan dengan bagaimana menata interaksi antara pebelajar dengan variabel-variabel metode pembelajaran lainnya. Strategi ini berkaitan dengan pengambilan keputusan tentang strategi pengorganisasian dan strategi penyampaian mana yang digunakan selama proses pembelajaran. Paling tidak ada 4 klasifikasi penting variabel strategi pengelolaan, yaitu: 1) penjadwalan; 2) pembuatan catatan kemajuan belajar; 3) pengelolaan motivasi; dan 4) kontrol belajar. Penjadwalan penggunaan strategi pembelajaran mengacu kepada kapan dan berapa kali suatu strategi pembelajaran atau komponen suatu strategi pembelajaran dipakai dalam suatu situasi pembelajaran. Pembuatan catatan kemajuan belajar mengacu kepada kapan dan berapa kali penilaian hasil belajar dilakukan, serta bagaimana prosedur penilaiannya. Pengelolaan motivasional mengacu kepada cara-cara yang dipakai untuk meningkatkan motivasi belajar pebelajar. Kontrol belajar mengacu kepada kebebasan pebelajar dalam melakukan pilihan tindakan belajar.

\section{Simpulan dan Saran}

\section{Simpulan}

Dari uraian penelitian, maka dapat disimpulkan sebagai berikut.

Pertama, telah dikembangkan model modifikasi kurikulum untuk sekolah inklusif berbasis kebutuhan individual peserta didik. Modifikasi isi kurikulum untuk anak dengan hambatan belajar tingkat ringan sekitar $20 \%$ yaitu Bahasa Indonesia $79.56 \%$, IPA 79.1\%, IPS 79,16\%, PKN $81,034 \%$ dan matematika $79,67 \%$. Kedua, model modifikasi kurikulum untuk sekolah inklusif yang dikembangkan mencapai $82.96 \%$. Ketiga, pemahaman guru dan kepala sekolah inklusif tentang isi buku panduan modifikasi kurikulum: Pemahaman guru dan kepala tentang isi buku panduan meliputi: a) Pemahamannya sangat baik $=$ jumlah 23 orang $(46,93 \%)$; b) Pemahamannya baik = jumlah 16 orang $(32,65 \%)$; c) Pemahamannya kurang baik= jumlah 8 orang $(16,32 \%)$; d) Pemahamannya tidak baik= jumlah 2 orang (4\%). Keempat, validitas empiris buku panduan, maka digunakan pedoman penilaiannya sebagai berikut: a) Kebermaknaan/Substansi buku panduan: sebagian besar $(88,2 \%)$ guru dan kepala sekolah telah menyetujui isi substansi buku panduan. Hanya $11,8 \%$ yang kurang menyetujui; b) Keterbacaan buku panduan: (1) Sebanyak $88,2 \%$ buku panduan telah menggunakan bahasa yang baik dalam penulisan, hanya $11,8 \%$ yang belum, yaitu buku panduan pemberdayaan lingkungan masyarakat dan manajemen sekolah dan, (2) Sebanyak $88,2 \%$ buku panduan telah menggunakan gaya penulisan yang singkat, padat dan baik. Sebanyak $11,8 \%$ tidak menjawab pertanyaan; c) Penampilan buku panduan. Penampilan buku panduan meliputi aspek ukuran buku, tata letak, tipe huruf, konsistensi penomoran, pewarnaan dan kesan umum tampilan buku panduan. Hasil analisis data menunjukkan bahwa sebanyak $64,7 \%$ buku panduan telah memiliki penampilan yang baik, selebihnya $29,4 \%$ belum baik dan $11,8 \%$ tidak menjawab pertanyaan.

\section{Saran}

Sambil menunggu finalisasi pengembangan model modifikasi kurikulum untuk sekolah inklusif. Maka sebaiknya sekolah dan guru di sekolah inklusif khususnya di jenjang SD/MI memulai melakukan penyesuaian-penyesuaian kurikulum dengan mendiskusikannya dengan guru-guru pendidikan khusus yang mendampingi sekolah yang bersangkutan.

\section{Pustaka Acuan}

Abdul Salim. 2005. Pediatri Sosial Dalam Pendidikan Luar Biasa. Jakarta: Direktorat Jenderal Pendidikan Tinggi, Departemen Pendidikan nasional.

Abdul Salim. 2005. Ujicoba model pendidikan inklusif di Indonesia. Jakarta: Ditbinlitabmas. Direktorat Jenderal Pendidikan Tinggi, Departemen Pendidikan Nasional.

Abdul Salim. 2008. Adaptasi Kurikulum, Pembelajaran dan Penilaian dalam Sekolah Inklusif. Jurnal Media Prestasi. Vol.III Nomor 2/Desember 2008. 
Abdul Salim, Munawir Yusuf. 2009. Pendidikan Anak Berkebutuhan Khusus Secara Inklusif. Surakarta: FKIP Universitas Sebelas Maret

Angela Valeo. 2008. Inclusive Education Support Systems: Teacher and administrator Views. International Journal of Special Education. Vol. 23 No.2 2008

Direktorat Pendidikan Luar Biasa. 2003. Mengenal Pendidikan Terpadu/Inklusi. Jakarta: Ditjen Dikdasmen.

Peraturan Pemerintah Nomor 19 Tahun 2005 tentang Standar Nasional Pendidikan.

Peraturan Menteri Pendidikan Nasional Nomor 70, Tahun 2009 tentang Pendidikan Inklusif bagi Peserta Didik yang Memiliki Kelainan dan Memiliki Potensi Kecerdasan dan/atau Bakat Istimewa.

Skjorten. 2000. Keeping tracks: Can Inclusion work?, A converzation with Jim Kaufman. Educational Leadership 52 (4) 7-11.

Stainbak W. Stainback. 1990. Support Network for Inclusive Schooling: Independent Integrated/educatio. Baltimore: Paul H.Brooker

Sunardi. 2005. Kecenderungan dalam Pendidikan Luar Biasa. Jakarta: Dikti

Sunarto. 2005. Metode Penelitian Pengembangan untuk Peningkatan Kualitas Pembelajaran.

Surat Edaran Dirjen Dikdasmen Depdiknas Nomor 380 /C.66/MN/2003, 20 Januari 2003 perihal Pendidikan Inklusif

Undang-undang Dasar Republik Indonesia, 1945.

UU Nomor 20 Tahun 2003 tentang Sistem Pendidikan Nasional.

Vaughn. Bos \& Schumm. 2000. Adaptive Mainstreaming, NY: John Wile. 